\section{En bok som gjør det lettere å lære histologi}

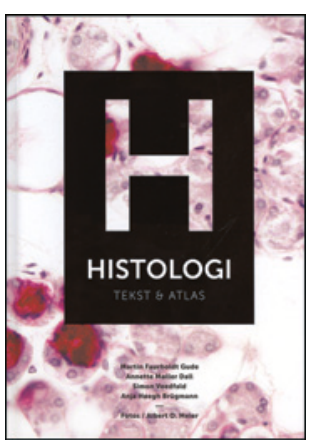

Martin Faurholdt Gude, Annette Møller Dahl, Simon Veedfald et al.

Histologi - tekst og atlas

434 s, ill. København: FADL's Forlag, 2015

Pris DKK 650

ISBN 978-87-7749-551-9

Så har det skjedd igjen - en ny lærebok i histologi fra Danmark. Hittil har Genesers histologi vært studentenes favoritt, ikke minst takket være at den er skrevet på dansk. Det er intet mindre enn imponerende at det finnes forfattere som tør satse på å utgi enda en bok innen et så begrenset marked som det her er snakk om. Når så likevel er tilfellet, skjer det med bravur.

Det foreliggende bokverket viser kvaliteter som gjør at det, uten tvil, også bør gjøres tilgjengelig for lesere utenfor Norden. Hva er det så som danner basis for dette utsagnet? Først og fremst fremstår læreboken som hendig både i format, layout og ikke minst i omfang. Dette med lærebøkers omfang er en særlig utfordring for forfattere. Med basis i å ville gjøre bøkene særlig aktuelle ligger det en fare for at et stort omfang av nyere forskningsresultater lett finner veien til lærebøker, og dermed bidrar til at de svulmer opp til å få et omfang som langt overgår det som er forventet at studenter skal tilegne seg i studietiden.

Forfatterne som her anmeldes, har på en forbilledlig måte unngått å lage et «monster» av en bok. Med et omfang på drøyt 400 sider makter de å formidle moderne histologi i et omfang som er godt tilpasset medisinstudiet.

I utgangspunktet er boken bygd opp på en tradisjonell måte, der vi kort presenteres for histologiske metoder for deretter å ledes fra cellenivået, via de forskjellige vevene, til de individuelle organene. Etter dette kommer det et kapittel på 12 sider som omhandler de forskjellige fargemetodene som benyttes i histologien. Det er et viktig tema som ofte får en stemoderlig omtale i andre lærebøker, men som bidrar til å gi studentene en god innføring i bakgrunnen for hvorfor de forskjellige cellene og vevskomponentene fremstår med de fargene de får på snitt.

Avslutningsvis er det et histologisk atlas som inneholder over 150 bilder. Både bildene i atlaset og de som ellers er knyttet til de forskjellige kapitlene, er av fremragende kvalitet. Figurtekstene er målrettede, og de mange fremragende tegningene, utført av medisinsk illustratør Ole Elmstrøm, bidrar i høy grad til å lette forståelsen. Det er bare snakk om originaltegninger og ikke en lang rekke lån fra andre bøker. Med slike tegninger kan man spare mye tekst uten at det går på bekostning av en helhetlig forståelse. Jeg anbefaler boken på det sterkeste.

\section{Edward B. Messelt}

Emeritus, Det odontologiske fakultet

Universitetet i Oslo

\section{Om partnervold, voldtekt og rettssystemet}

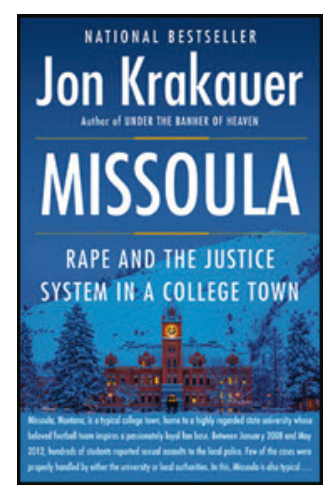

Jon Krakauer

Missoula

Rape and the justice system in a college town. 384 s. New York, NY: Doubleday, 2015.

Pris USD 29

ISBN 978-0-38553873-2

Dokumentarskribenten og journalisten Jon Krakauer har skrevet en kjønnsforskningsinspirert bok om voldtekt, og han skal ha honnør for å ytre seg tydelig om dette triste fenomenet. Krakauer tar oss med til et collegemiljø i Missoula i dagens USA.

Forfatteren demonstrerer at voldtekt er vanligere enn vi tror, og at ofrene nettopp ofte er jenter i den aldersgruppen som studerer. Han går gjennom fakta om forekomsten av voldtekt, de medisinske konsekvensene og betydningen for fornærmede med en saklig tørrhet. Det er imidlertid ikke saklig tørrhet som preger resten av boken.

Boken er nesten oppbygd som en kriminalroman. Forfatteren tar oss med til ulike scenarioer, bygd på intervjuer han har med voldtektsofre, rettsutøvere og skolefolk. Han dokumenterer gang på gang hvordan alminnelig ungjenteatferd, som å tøyse med venner, gå på bar, drikke litt, flørte og surre litt rundt, uten spesielle forvarsler, utvikler seg til hendelser der vold, overgrep, mangel på respekt og skrekk blander seg inn, og jenta, på ulike måter, ender opp voldtatt av en hun kanskje kjenner litt.

Krakauer følger noen utvalgte saker videre, fra selve voldtekten til skrekken og paralysen etterpå, forsøk på anmeldelse og forsøk på å reparere skaden. Posttraumatisk stress - hvordan det utvikles og forsterkes av prosessene etterpå - får en beskrivelse og et ansikt som virker troverdig.

Verre er det man møter i universitetssystemet og på politikammeret. Her tar Krakauer oss med på et spill uten regler. Han viser hvordan universitetssystemet svikter de unge jentene, fordi institusjonens rykte blir viktigere en jentas ære og oppreisning. Det er nemlig ofte universitetets gullgutter som er utøvere av volden. Politiet har medlemmer av sin stab som heller ikke synes synd på jenter som voldtas, og som ikke tror på dem. Krakauer demonstrerer, gjennom konkrete eksempler, hva ordet «reviktimisering» betyr. Å anmelde voldtekten kan slå tilbake på en selv. Han viser hvordan systemet ydmyker jentene og setter deres troverdighet på spill. Han viser også at noen voldtektsforbrytere klarer å bli frikjent, og at det er nokså tilfeldig i hvilke saker jenta får medhold eller ikke. Ledelsen i politiet og på universitetet tar ikke tar grep for å bli kvitt problemet.

Boken er mer enn bare god. Dokumentasjonen er prikkfri. Referansene er som om dette var en vitenskapelig rapport. Jon Krakauer mestrer fortellingens kunst. Hans moralske forankring er at voldtekt er underkommunisert og skrekkelig, og at alle instanser svikter jentene. Han overlater til leseren å trekke slutninger ut over det. Leger i allmennmedisin, gynekologi, samfunnsmedisin og rettsmedisin bør sluke denne teksten. Den gir oss flere fasetter av et grimt samfunnsmedisinsk dilemma og likestillingsproblem vi ikke har full kontroll på.

Johanne Sundby

Professor, Seksjon for internasjonal helse

Universitetet i Oslo 